\title{
The Social Question All Over Again
}

Jan Breman, Kevan Harris, Ching Kwan Lee, and Marcel van der Linden

Want, Disease, Ignorance, Squalor, and Idleness. These were, according to the British liberal reformer William Beveridge, the enemies of social progress. Together, the five "giant evils" express the so-called social question: that is, the problem of indigence and destitution on a mass scale. Originally a French notion, created more than two centuries ago (la question sociale), the social question became the leitmotiv for the many laws and policy measures in the nineteenth and twentieth centuries that resulted, in a relatively small part of the world-in capitalist welfare states and some "state-socialist" societies-in extensive protective arrangements for the disabled, the old, and the unemployed, as well as in health care, housing, and education accessible to (almost) all. Due to uneven development of capitalism on a world scale, however, working people in colonized and dominated Africa, Latin America, and Asia were excluded-indeed, necessarily-from the benefits and progress of the Global North. Between the 1970s and 2010s, global development has slowly led to the return of the social question with a vengeance, but without the assertive engagement that had made it publicly visible and politically urgent in earlier times. The decline of average profit rates in "old" capitalist countries, the collapse of state-socialist competitors to capitalism, and the concomitant rise of neoliberal ideologies have brought turmoil to the vast majority of the world's working population. The pernicious effects of mass immiseration have found poignant political expressions in, on the one hand, the surge in ultraconservative, nationalistic, and populist politics and trends (such as the election of Donald Trump, Britain's exit from the European Union, and xenophobic rejections of refugees arriving in Europe), and on the other, the mass protests and occupy movements against austerity and crony capitalism. And yet, the worldwide erasure 
of the "social" in favor of self-employment and self-reliance emphasized by neoliberal ideology has repressed the social question from public discussion.

This introduction offers a stylized global overview of the evolution of the social question since it was first articulated in nineteenth-century Europe. We attend to both its discursive constructions and its material and political manifestations. But first, it is important to differentiate the frame of the social question from the dominant paradigm of "poverty alleviation." The disappointing outcome of the postwar decades of developmentalism led to the declaration of the Millennium Development Goals at the end of the twentieth century, making the worldwide reduction of poverty the prime objective. Fifteen years later, equating the march to human progress with poverty alleviation and the diminution of development policy to this shallow ambit has been hailed as a remarkable success story. The country and regional case studies collected in this volume mount a major rebuttal to this assessment. The empirical findings in this book show that the persistent belief in a trickle-down spread of the benefits of economic growth to the subaltern classes is an illusion that ignores an accelerating immiseration resulting from dispossession, dislocation, and disenfranchisement.

It is not just the failure of poverty alleviation as development policy that gives us pause. There is an important conceptual difference between poverty and the social question. Poverty exists when people find it difficult to make ends meet. The deficit forces them to make painful choices, some of which are temporary in nature or restricted in magnitude and are made manageable by deferring gratification, occasionally or forever, of needs given a lower priority. Destitution, a more severe and chronic grade of misery, requires not incidental but institutionalized support to safeguard even sheer survival. Whereas the notions of poverty and destitution allude to the personal, immediate, and often irreversible deprivation afflicting people in that predicament, the social question points to the relational, institutional, and political economic forces constitutive of destitution as a historically specific phenomenon. As Marcel van der Linden elaborates in his contribution to this volume, the understanding and assessment of destitution as a social issue demanding public awareness, legal mediation, and state intervention did not come about until the great transformation in nineteenth-century Europe. It was linked, on the one hand, to the increasing commodification of social relations and the concomitant transition from an agrarian-rural to an industrial-urban economy and, on the other hand, to a social consciousness expressing solidarity spearheaded by an emancipatory working-class movement in Europe.

\section{HISTORICAL TRAJECTORY OF THE SOCIAL QUESTION}

\section{Pre-Capitalist Responses to Indigence}

Indigence did exist in the pre-capitalist era, before commodified labor relations became widespread, perhaps as far back as European antiquity, but historical 
research on this issue is underdeveloped. ${ }^{1}$ In many pre-capitalist agrarian societies, huge differentials in wealth and income could exist, but often the poorest layers of society were at least minimally protected by forms of communal relief. Frequently, better-off agrarian or artisanal households were obliged to chip in to extend support to deprived neighbors in their small-scale midst. In Europe's late Middle Ages, for example, communal relief was institutionalized at the local level in the Poor Laws, which lightened the burden of improvidence. Redistributive mechanisms were usually endorsed by a religious code prescribing charity, as, for instance, provided by the collection of zakat, a payment in kind or cash made under Islamic law. To prevent or at least slow down an unwelcome trend toward increasing dispossession, many peasant societies utilized the custom of the commons, which implied open access to resources jointly held nearby, such as waste land or water, to members of the same rural community. A periodic redistribution of cultivated land, as, for instance, in the traditional Russian mir or among indigenous tribes in South America, was a more rigorous way to preempt progressive differentiation in property and power. Were such customary arrangements, which pressed for some modicum of redistribution, a feature of all peasant societies? It seems likely that a large part of humanity used to live and work in societies marked by inequality in all walks of life.

Capital accumulation, commodification of land and labor, and dispossession of peasants and artisans went hand in hand. This trend first became visible in Europe when the medieval communitarian economy that still leaned toward autarky was finally destroyed. Varieties of feudalism had eroded peasant property while silencing the voice of the victimized peasantry. In his early Memoir on Pauperism, published in 1835, Alexis de Tocqueville wrote, "from the moment that landed property was recognized and men had converted the vast forests into fertile cropland and rich pasture, ... individuals arose who accumulated more land than they required to feed themselves and so perpetuated property in the hands of their progeny." ${ }^{2}$ As a consequence of the enclosure movement, the large estates in England became even larger and were operated more commercially. Max Weber's treatise on the agrarian question is equally relevant for understanding how the social question was handled in the rural past. Elaborating on the concept of patrimonial rule practiced in the eastern German provinces, he characterized the relationship between the landlord (Junker), who maximized power and status instead of production, and the farm servant, who was tied to his employer's household on an annual contract in which he received discretionary benevolence for the permanent use made of his labor power. It was a form of attachment marked by exploitation as well as patronage. ${ }^{3}$

\section{The Great Transformation in Europe}

Taking stock of a large amount of data collected in a survey toward the end of the nineteenth century, Max Weber, who was commissioned by the Verein für 
Sozialpolitik (Association of Social Policy) for this analysis, focused his attention on the inroads capitalism had made in the rural economy. A drastic change in the crop patterns, caused by a higher volume of international trade, led to a pronounced seasonality in the cultivation cycle. In reaction to increased commercialization, estate owners had started to replace their attached workforce with casual labor hired only when their presence was required in peak periods. Swarms of seasonal hands from Poland and Russia_ "barbarian hordes," in Weber's vocabulary-with less physical ability but willing to work on very low wages, flooded the countryside of eastern Germany in the busy months, only to disappear again when employment fell. Landlords were no longer willing to guarantee the livelihood of agricultural laborers in the relentless drive to proletarianization. While seasonal migrants were hired when needed, the local landless could not survive on temporary, off-and-on work. They had become superfluous to demand and took off to the city to find employment in industry, construction, or other sectors of the now rapidly expanding urban economy.

A similar turn had taken place in Great Britain somewhat earlier on. A drastic revision of the Poor Laws in 1834, two years after the middle classes had gained suffrage under the 1832 Reform Act, took away the public relief that, since the medieval era, had been provided locally to unemployed labor in times of need. Forthwith, it was provided exclusively to the non-laboring poor-the elderly, widows, the handicapped, and the chronically ill. Their dole was granted only when they were fortunate enough to pass the "means test," confirming that they did not get support from relatives or other donors. Parliament, which still mainly consisted of members hailing from the landed aristocracy, debated why and how to amend the Poor Laws. The immediate ground for the amendments seemed to be the growing resistance of the non-poor to contribute to a public fund spent on labor labeled as unwilling to search around for waged work and thus take care of their own sustenance. Hidden sentiments behind expressing annoyance against what was portrayed as a "free rider" mentality were inspired by a steadfast refusal to accept maintenance of the idle poor as a burden to the commonweal in which the non-poor must share. Summing up the essence of the amendment, Karl Polányi wrote, "No relief any longer for the able-bodied unemployed, no minimum wages either, not a safeguarding of the right to live. Labor should be dealt with as that which it was, a commodity which must find its price in the market." ${ }^{4}$ A covertly held consideration was the impelling need to drive the land-poor and landless away from their rural habitats, in which they found minimal security in times of distress, and to urban growth poles to feed the local stock of labor required for the new industrial economy.

\section{Disqualified from Relief}

The revision of the Poor Laws formed the main push for the falling from grace for many throughout Europe. This turned agrarian workers, who had always been 
stakeholders, into outsiders from the commonweal, once they lost their regular jobs and were hired off and on as casual hands. They were no longer eligible for public relief when unemployed. Over time, and as a consequence of the lengthening chain of dependency far beyond local reach and control, the segment cut loose from wherever it belonged in terms of work and life rapidly increased. Their rise to an abundant number with the worldwide advance of capitalism, multi-class in origin and joining the ranks of the stigmatized lot, is captured well in Karl Marx's description of what he rather disparagingly called the Lumpenproletariat. 5 Due to ongoing dispossession, the land-poor and landless classes in European countries had rapidly increased in size and were forced to vie for sources of livelihood other than what had been the prime sector of the economy in previous generations. The transformation went together with a major restructuring or destruction of artisanal forms of production. An accelerated footlooseness of adults, as well as minors, occurred within the countryside, but mobility from village to town or city increased even more. Sprawling urban locations required the presence of massive armies of labor for the transport and storage of a steadily growing volume of goods, not only at expanding industrial work sites but also for building up an infrastructure consisting of railway lines, stations, canals, dockyards, roads, and warehouses. The exploitation of men, women, and children ruthlessly put to work in the intensified process of economic activity-and their total lack of wherewithal to cope with the commodification to which they were subjected-led to stark poverty and pauperization. It was a consequence of capital becoming dominant in the new landscape of economic production.

\section{The Struggle against Adversity and the Northern Class Compromise}

The deterioration in livelihood caused by loss of employment as well as habitat instigated new forms of social security. As a first step, many from the ranks of the somewhat better-off and more regularly employed wage earners organized mutual-aid societies, usually beginning as small-scale, local operations, but gradually becoming interregional and even national. These forms of social security excluded, however, significant segments of the working population. Women were usually not admitted, and the poorest workers were not eligible because of their fluctuating and insufficient incomes. ${ }^{6}$ Ongoing pauperization of the "dangerous classes" on a mass scale, their sporadic violent and rebellious behavior, and their deteriorating health combined with new forms of trade-union actions, leading to more encompassing forms of association in which claims for improvement were articulated. From the late eighteenth-century, trade unions began to organize the workforce; after 1848, their strength increased and, backed up by industrial action, they gradually succeeded in institutionalizing forms of collective bargaining. The threat of straightforward confrontations between capital and labor was avoidedor at least mitigated-when the state, through a variety of regulations, started to defuse the risk of havoc, which, in all likelihood, would have resulted from a 
head-on clash between them. Mediation was operationalized through extensive labor legislation that made basic rights of the workforce mandatory, such as fixing minimum wages (and a hike, in case of price rise), steadily lowering the ceiling for hours at work, and, in case of dispute, requiring obligatory arbitration.

The transformation that occurred until and beyond the middle of the twentieth century has resulted in a relative rise in working-class power in what were, of course, still capitalist societies. The social struggle that came about in industrializing and urbanizing Europe had two major components. In the first place, better conditions of employment ensued, such as higher wages; a change from piece rate to time rate; a shorter working day, week, and life; safety at work; paid leave; and a premium on schooling and skilling. All this culminated in a standard contract that conceded the right to collective action and representation. ${ }^{7}$ In the second place, the provision of social security and protection took shape, which included health insurance, a pension fund for the aged, allowances in case of injuries and handicaps while at work, gratuities or bonuses, and, to cap it all, compensation for loss of employment.

\section{Growth of the Welfare State and the Public Economy}

What initially had been posed as a labor question, pure and simple, metamorphosed into a wider question expressing aspirations for a decent and dignified mode of existence. The deepening of public authority climaxed in the emergence of the welfare state that slowly came about in this part of the world during the first half of the twentieth century. An important element of the social progress made in Europe was the extension of suffrage, first for adult men and, belatedly, for women as well. The social question transfigured from the realm of labor to the realm of citizenship at large. The universalization of social security provisionsincluding medical insurance, compulsory education at young age, pension rights, unemployment and disability benefits, widows' and orphans' support, and supplemented, after World War II, by child benefits and an old-age allowance-often extended to a large segment of the population and made an important contribution to their well-being. In the righteous jargon of politicians and policy makers, this was known as care "from the cradle to the grave." Memories of the trente glorieuses, roughly from 1945 to 1975, evoke feelings of nostalgia. The working classes of the erstwhile Second World would have ample reason to share those sentiments.

Conditional to the realization of the ambition to raise people's standard of life was the intervention of the state machinery in building up a much larger and strengthened public economy than had existed before. The first steps toward this attempt to bring the former notion of the commons to the national level were taken in the late nineteenth and early twentieth centuries, with the establishment of municipal utility corporations for gas, water, and electricity and for garbage and sewage disposal, as well as sanitation. Cooperative housing societies, the postal 
and telephone services, public transport and insurance authorities were set up to cater to the commonweal and public works to upgrade the physical infrastructure. And, to top it all, public health and education became schemes of welfarism. The creation of the welfare state was inextricably linked to the emergence of public institutions, space, and agency. The flipside of a steadily expanding public domain was, of course, higher (albeit income-differentiated) taxation and increasing bureaucratization. ${ }^{8}$

The so-called Second World of the Soviet Union and its allies in Europe, as well as in the world at large, claimed to have put the social question at the top of the national agenda. After all, in its revolutionary origin was the promise to end the exploitation and suppression of the working classes by capitalism. In China, the urban laboring class employed in state-owned enterprises was a minority in a system that excluded the vast majority of rural producers and urban temporary workers from its iconic state paternalism. As Ching Kwan Lee documents in her contribution to this volume, even this exclusionary socialist welfare system gave way to a secular process of precarization and political exclusion for labor. The disappearance of the only alternative to capitalism lifted the pressure on Western democracies to demonstrate the superiority of their system through welfare provision.

\section{Falling behind and the "Southern" Class Compromise}

Vast tracts of the planet had remained exempt from the march of progress, resulting in what turned out to be a time-bound social compact. The Global South, made up of societies and economies subjected to (semi-)colonial rule imposed from the metropoles in the Global North, fell behind in stagnation. The split in the global working class, having its origin in the uneven path of development, with colonialism as a major cause, eventuated in a growing segregation between frontrunners in the Global North and latecomers in the Global South. After the abolition of slavery, new forms of unfree labor were introduced, on the pretext that the limited needs to which the "natives" were habituated made them work shy. It led to the recruitment, in the backward economies, of armies of indentured coolies deployed worldwide to enclaves of capitalist production, such as mines and plantations in the southern hemisphere. The work contracts in which they were entrapped could not be reneged, and protest or resistance against the harsh labor regime was brutally punished. The major part of humankind remained embedded in village-based economies, producing food mainly for their own livelihood. The low-level technology explained why these small-scale peasant communities went on to live and work from generation to generation without much change and were, in years of scarcity, supposed to help each other out in a pattern of shared poverty.

Sustained and intensified colonial rule was now portrayed as a civilizing mission with the pledge to "add value" where it was considered to be absent. In the early twentieth century, the international alliance of social-democratic parties 
endorsed the French proclamation of this mise-en-valeur thesis. ${ }^{9}$ It meant the endorsement and propagation of a racist doctrine that justified the ongoing subordination of the "lower" segments of humanity held back in an imperialist setting. On the eve of independence from colonial rule, only a tiny fraction of the total workforce-a privileged contingent of modern factory hands and office workers mainly-had come to enjoy formalized conditions of employment. The large majority of men and women engaged in waged work were firmly stuck in labor relations that remained thoroughly informalized. The formal-informal divide that became so prominent in the late twentieth century has its origin in labor policies of the colonial period.

In the wake of decolonization of the Global South around the mid-twentieth century - though Latin America had gotten rid of formal colonialism earlier oninternal developments in the Global South led to a "southern class compromise." Rapid urbanization in the developing countries from 1950 to 1970 compelled governments in Latin America, the Middle East, and North Africa to pacify the urban popular groups consisting of both poor and middle classes with price subsidies, public services, and other forms of social wage guarantees. As Kevan Harris shows for the Middle East and North Africa, nationalization of major industries and expansion of state bureaucracy made the public economy a major provider of formal employment. This pact of developmentalist populism was orchestrated by a class coalition of state bureaucracy and industrial and export interests that paid the price of social peace with concessions to urban dwellers. ${ }^{10}$ National sociopolitical formations shaped the particular mode of compromise. In South Africa, as Ben Scully discusses in his chapter, the settler colonial response to the social question was in the form of a whites-only welfare state, a racialized social compact that excluded the majority black population. Overall, whereas in advanced industrial societies the compromise was essentially an exchange between organized capital and organized labor, the southern class compromise was driven by the state, which incorporated and subordinated urban labor. ${ }^{11}$ As Ronaldo Munck and Mao Mollona examine in Latin American cases, since the mid-1970s, this class compromise has begun to unravel, as southern states plunged into a sustained debt crisis and International Monetary Fund-inspired adjustment programs triggered widespread austerity protests by the urban classes.

The International Monetary Fund and the World Bank, the two transnational corporations set up by the Bretton Woods system of financial management, expanded their original mandate, which had mainly focused on the advanced economies. Increasingly, both agencies started to extend their operations to the provision of loans to developing countries with conditionality clauses meant to prevent or undo fiscal imbalances. Announced as structural adjustment programs (SAPs), policies were advocated that privatized and deregulated what had been the prerogative of state-directed welfare management exercised by the national treasury. Andreas Eckert has commented on the impact of this policy in Africa. 
No transnational agency was set up to handle the social mandate. Instead, Poverty Reduction Strategy Papers (PRSPs) were announced to suggest that higher rates of economic growth in the catching-up countries were both a necessary and sufficient condition for welfare to trickle down. The fading away of the state as a broker between capital and labor was the outcome of the neoliberal strategy that first became mandatory in the Global South. After the turn of the century, it was also imposed on the Global North and became increasingly dominant the world over. In the former Soviet bloc countries, the shift that endeavored to boost the "free market" led to much reduced funding on social-sector expenditure and a major contraction of the sizable public economy. Carine Clément shows in her chapter how shock therapy in Russia in the 1990s took a heavy toll on Russian workers and their families and led to a rampant normalization and individualization of precarity. Don Kalb similarly highlights how liberalization and market reforms in post-socialist Eastern Europe undermined the strong and militant solidarities of the 1980 s labor movements in the region.

\section{THE RETURN OF THE SOCIAL QUESTION UNDER GLOBAL CAPITALISM}

In drawing the final balance of the Millennium Development Goals, bringing a growing number of people above the threshold of deprivation is highlighted as the successful outcome of neoliberal policies. The World Bank's felicitous observation of gradually diminishing indigence all over the world-from 14.5 percent in 2011 to 12.8 percent in 2012 and, hopefully, to below 10 percent in 2015-stems from fixing the takeoff point at a budget considered to be adequate for the poorest countries in the world. In 1990, when the global poverty line became set for the first time, the yardstick was the ability to spend not less than one dollar a day per capita, the international poverty line based on the purchasing power parity (PPP) index. After a hike of this amount to $\$ 1.25$ in 2005, it was further raised to $\$ 1.90$ in 2011 in order to account for rising prices. In this statistical exercise, the growing part of the population sliding downward in the advanced economies is totally disregarded. It is an oversight compounded by the assumption that indigence is a condition that is absolute. It defies the point of view that poverty should be perceived as a lack of means defined both in relative as well as relational terms. The global downfall is not one of capitalism, as Immanuel Wallerstein has already been arguing for a number of years. ${ }^{12}$ It should rather be understood and tackled as an increasing shortage of gainful employment and too low a price for rewarding an incessantly growing workforce in the world. One result of the globalizing economy is that the dominating trend of increasing inequity appears to indicate a growing divergence between social classes. While inequality between countries is slowly decreasing, inequality within countries is rapidly growing. For the Global North, Thomas Piketty has amply documented the enrichment of owners and managers of capital. ${ }^{13}$ 


\section{Divergent Trajectories between the Global North and Global South}

The notion that postcolonial countries, in the aftermath of the successful fight for national sovereignty, would be put on the track to progress by their erstwhile rulers pretending to be inclined to more altruistic policies than before was met with skeptical appraisals. To start with, it is an evolutionary imagery that does not acknowledge a substantial drain from the Global South during the era of colonialism in building up the lead position of the Global North. The early growth trajectory in the Atlantic basin had partly been achieved by extracting surplus from countries in the Global South caught up in a stultified, backward rural economy. These transfers-written up as a drain in the dissenting literature-contributed to the in-country process of accumulation going on in the Global North. To this critical assessment, other major diversions in the differential growth and development trajectories in the world, separated from each other in a prolonged time span, should be added. The most significant of these other distinctive features were limits to demands for labor and a drastically changed appraisal on the role of migration.

Of major importance is the much lower land-labor ratio in mid-nineteenthcentury Europe as compared to the much higher pressure in the mid-twentieth century on agrarian resources elsewhere, particularly in Asia. While the push away from agriculture and the countryside amounted to a ballpark figure of 120-150 million people in Europe between 1850 and 1914, the exodus going on one century later out of the major countries of Asia easily adds up to a staggering above 700 million mostly land poor and landless peasants. Driven out by a stark lack of employment and income opportunities in and outside the primary sector of production in the countryside, a major segment of these uprooted masses of migrants try to establish a foothold in the expanding urban economy. However, while work in industry became an alternative after the loss of agrarian-rural livelihoods in erstwhile Europe, it has remained modest in size in the postcolonial societies. This means that the newcomers to the towns and cities of the Global South are dependent for employment on earnings made in construction, transport, petty trade, and services. Even in China, reputed to be today's workshop of the world, industrial jobs employ less than half of an estimated 300-350 million migrants who have left the countryside during the last quarter of a century. In India, as well as in other Asian countries, the size of the industrial workforce is still much lower, even if we include self-employed and mainly home-based manufacturers along with factory labor. Prospects of acceleration in industrial activity, providing jobs to a much larger percentage of the total workforce, are slight. While the first stage of the industrial revolution in the Global North continued was highly labor intensive, the transition to more advanced technology-first mechanization and automation, followed by computerization and robotization-has steadily given rise to a more capital-intensive mode of production and jobless forms of economic growth. 
Centuries earlier, when the European countryside started to depopulate, part of the redundant labor in agriculture did not migrate to towns and cities within the same country but left for destinations overseas. This transfer mitigated the pressure on the swollen labor market at home. These earlier waves of emigrants settled down in the underpopulated zones of the planet-North and South America, southern Africa, Siberia, Australia, and New Zealand-to find better livelihoods than they had enjoyed before. The underpopulated territories on the global frontiers happened to be inhabited by tribal communities driven off or wiped out in the march toward what was claimed to be a higher level of civilization. There are no more "empty" regions in today's world. ${ }^{14}$ People nowadays, driven by distress and trying to get out of the Global South in desperate search of work and life, are no longer classified as brave colonists who are bid welcome to settle down in their country of arrival but have become labeled economic refugees. If escape from poverty is their aim, they are even less welcome than newcomers better equipped with skills and physical as well as social capital to provide for their livelihood.

\section{Informalization of Labor and Capital}

By the turn of the new millennium, through different trajectories, the standard labor contract as part of the post-WWII class compromises in the Global North and the Global South has substantially unraveled. Informalization of labor has by leaps and bounds become a global trend. Its major features are as follows: no regulated jobs backed up by a labor contract, but hire-and-fire, according to the need of the moment; a variable length of the working day, fluctuating between too short or too long; extensive participation in the paid labor process at both underage and overage; no standardized wages with a fixed minimum, but piecerated remuneration imposed unilaterally and individually by the employer or his agent; erratic payment, either given by way of advance or settled afterward, but in both cases, a modality meant to reduce the labor price; injurious working conditions at sites that are unclean, unhealthy, and hazardous or dangerous, leading to occupational diseases and accidents; no safeguard against dismissal, loss of labor power, and unemployment; and self-representation instead of collective bargaining and forced self-employment coupled with self-provisioning. The case studies presented in this volume bear witness to the practices of informality and informalization throughout the world. We cannot deny, of course, that huge differences in per capita income continue to exist between North and South. In the Global North there are still some vestiges left of the deal closed with labor when the economy was predominantly run along formalized lines of employment. Indigence in size, shape, and degree is much starker in the Global South than it has become once more in the Global North.

Not just labor, capital is also increasingly informalized. Labeled as a black circuit, massive financial transactions move around the globe, unregistered in governmental bookkeeping and beyond the reach of the national exchequer. Gabriel 
Zucman estimates that $\$ 7.6$ trillion, or 8 percent of the world's financial wealth, is held in tax havens. In Africa, the proportion is as high as 30 percent; in Russia and the Middle East, above 50 percent. ${ }^{15}$ The black money in circulation is difficult to estimate but might be close to or even larger than the amount of cash legally changing hands. Free market enterprise happens to be backed up by a political order at the level of the nation-state willing to go along with the directives of predatory capitalism. Handicapped by the absence of forceful and effective public governance in the global realm, it seems rather farfetched to presume that financialized freebooting, which has a strong lobby in privatized banking, will eventually be brought under public control. ${ }^{16}$

All over the world, rich and poor have disappeared from each other's presence and even sight. They live in different circuits, and that lack of interaction means that the moral bearings of the social question got lost. Does the thoroughly informalized workforce in the global economy constitute a dangerous class? In our view, it might be more appropriate to label the down-and-out masses as an endangered species, no longer embedded within the rights of citizenship in mainstream society. ${ }^{17}$ Take the case of the street vendor in a small Tunisian town who ended his life in self-immolation. Having failed to find a regular job, his efforts to scratch around at the bottom of the urban economy were met with police harassment, and in agony, he ended his life when his livelihood of the last resort was taken away from him. Such acts of defiance, though not rare, usually remain unseen and unheard in public space, but not in this instance. His refusal to bow down under lack of work and freedom fueled an outburst of popular anger. Demonstrations spread like wildfire and swept throughout North Africa and the Middle East in opposition to political, economic, and social tyranny.

\section{Strains on Family and Reciprocity}

In his contribution, Dennis Arnold highlights how, under the development regime the Asian Development Bank has imposed in Mekong South East Asia, "pro-poor" growth enclaves are set up that reproduce poverty rather than ameliorate it. The workforce is employed on an informal footing, and the migrants engaged, not earning enough to make a living, have to remain encapsulated in a fragile agrarian economy to do so. People steeped in progressive adversity have no other wherewithal than to fall back on makeshift solutions of long standing, such as support from family, neighbors, and others close to or far away from where they work and live. It is the low-profile way of mutual assistance, small-scale attempts to ward off setbacks by sharing expenses on life-cycle events or seasonal ups and downs among people in the same setting. But out of necessity, households have often become multi-locational, with members-both adults and children-pushed off to go wherever and for as long as waged work can be found. To bring dependents along would be an unbearable burden. As they drift away from home, the imposed mobility means that life for such labor migrants tends to become individualized, 
deprived from the nearby comfort of parents or offspring. Claims on reciprocity put enormous strains on family relations. It explains why destitution is often an ordeal that coincides with a break-up of the household and ends in alienation and loneliness. Ben Scully's chapter spotlights in particular the strain on the family, especially the women, as central organizers of informal welfare and survival among South Africa’s poor.

\section{Land Flight}

Another coping mechanism for the surplus population is emigration, an option that has increasingly become perilous. In the receiving countries, migrant workers form a marginalized underclass depleted of minimal protection against exploitation and oppression, as has become standing practice over the last half century, for example, in the Arab Gulf region. A doctrine of naked racism has emerged in many parts of the world, made manifest in autochthonous domination versus alien subordination. Labor in the globalized economy is prevented from uniting and fighting for their common interest-decent work and dignified life-by promoting fault lines of segregation along what are considered to be primordial loyalties, such as gender, race, ethnicity, creed, caste, and nationality. It means that no common claims can be derived from the laboring status, since they clash with what are perceived as first-order sentiments.

The contingents of refugees from the Global South desperately trying to reach a safe haven in Europe, Russia, North America, or Australia tend to be equipped with an identity somewhat higher up in the class ranking, have enjoyed some degree of skilling or schooling, and, with familial support, are able to buy their way outside. They cross frontiers sans papiers and travel in the hope of good luck, often without knowing in advance where they will end up or wash ashore. Depots have been established either halfway or on the receiving end in which these flotsam and jetsam castaways are held in isolation, locked up because they have been found guilty of unauthorized trespassing at some point during their often ill-fated journey. In the middle of the twentieth century, the term displaced person (DP) was coined for the registration of people who had lost hearth and home. Half a century later, the abbreviation seems to express the fate of dumped people, arrested and detained out of sight for being a nuisance to citizens with a legal status of residence. When politicians insist that refugees have to be dealt with in or close to their country of origin, it is in euphemistic reference to detainment in permanent exile, end-stations for people considered to be surplus to demand. How to handle their presence? The simple pretense is that they are not there, have no right to existence, and building walls is not really necessary to keep them in a state of invisibility. Sheer lack of connectivity with faraway destinations, together with lack of money to pay the high price of the often illegal and tortuous passage, leaves them entrapped at home. The reserve armies of labor amassed in the Global South are stuck in a prolonged state of un- and underemployment, cut 
off from regular and decently paid jobs that, in their dreams, are available elsewhere. Together with the non-laboring poor, they are in rapidly growing numbers exposed to pauperism.

Earlier solutions for how to close or at least reduce the gap between prosperity and poverty were based on the logic of proportional representation and distributional justice, pertinent to an ethos of equity that aimed at structuring economic, political, and social life. The progressive disequilibrium has not prompted politicians to reconsider their policies of leaving the staggering bonanza of riches untaxed. Instead, they have opted to further reduce taxation and thus add to the sharply skewed splits of the spoils by rewarding capital with more subsidies and exemption from regulations prohibiting environmental degradation, pretending that this will stimulate employment. The strategy has allowed capital to escape again from societal control, but now in a context that is different from the one Polányi described and analyzed for the Western economies in the mid-nineteenth century. ${ }^{18}$ In contrast to what happened then in this part of the world, re-embedding capitalism again within the perimeters of the nation-state is a moot possibility. While the drive to play along with the free operation of casino capitalism goes on as before, and a much required levy on financial transactions is not enacted, at the other end of the scale, the laboring and non-laboring poor are wont to bear the brunt of a fiscal policy that has led to a drastic underfunding of the budget spent on the social safety net. The punitive welfare reform, as designed and executed in the United States since the late twentieth century, as Fred Block details in his chapter, might become standard for dealing with the chronically unemployed in the front-running as well as the "catching-up" economies. ${ }^{19}$

Across the Global South, the social question on national agendas has taken the form of recently proposed or implemented social policies, such as small-cash transfers, old-age pensions, meager-workfare schemes, or basic-income grants. Poorer segments of the population that have gained newly available access to state-provided transfers, as in Brazil or South Africa, never had previous access to formal sector or employment-based welfare provisions. It remains to be seen if these low-quality and much restricted safety nets will have significant and lasting impacts in benefiting the poor. One objection, of course, is that a dole solely in the form of a state-provided cash transfer to the impoverished underclass does not even ameliorate the real situation of human immiseration. Evidence on the positive effects of the wide variety of new social policies across the Global South has to be matched with cases that demonstrate sustained or even hardening exclusion, as Jan Breman shows in his chapter on Indian social policies. Of even more significance than putting on record this diversity in graded practices of inclusion versus exclusion would be to point out that the strained public budget in the prolonged setting of neoliberalism does not allow governments to spend much on what is minimally required to keep the poor masses free from want, let alone provide them with income enabling a somewhat dignified livelihood 
beyond sheer reproduction. In much of the Global South, such down-and-out people seem to have wasted their value as a commodity, let alone their human quality.

\section{COUNTERMOVEMENTS AT THE GLOBAL LEVEL?}

\section{Trade Unionism}

Why and how has the social question failed to become raised and solved, when capital transcends beyond the nation-state and operates in predatory fashion at the globalized level? The main agencies charged with promoting the interests of the working classes in the world at large are a conglomerate of country-based trade unions and the International Labour Organization (ILO). Large-scale workingclass movements had their origin in the nineteenth century in the North Atlantic basin. When, in the interwar years, interest in trade-unionism increased in the peripheral and semi-peripheral countries, it was the Communist Red International of Labor Unions (RILU or Profintern), which, after its founding in 1921, sought to put down roots in the Global South. The International Federation of Trade Unions (IFTU) followed a few years later, from about 1928, partly to counter the rival Communist organization, which was intent on gaining greater influence in the colonial and semi-colonial countries. The IFTU and its successor, the International Confederation of Free Trade Unions (ICFTU), were both dominated by the British TUC and the American Federation of Labor and Congress of Industrial Organizations (AFL-CIO), and had the reputation of being allies of colonialism and neocolonialism. Such suspicions were not entirely unfounded. The ICFTU tried for years to propagate a certain "model" of "proper unionism." One of the aims formulated at the time of its founding in 1949 was "to provide assistance in the establishment, maintenance and development of trade union organizations, particularly in economically and socially under-developed countries." ${ }^{20}$ It was assumed that "proper" trade unions would remain fully independent of political parties and states; concentrate on collective bargaining and lobbying for social security legislation; and defend and promote parliamentary democracy. These principles often proved difficult to apply. ${ }^{21}$ For a genuine collective-bargaining system to work, there are preconditions not found in many countries, including "a legal and political system permitting the existence and functioning of reasonably free labor organizations" (a condition that was fully compatible with the early ICFTU views) and the requirement that "unions be more or less stable, reasonably well organized, and fairly evenly matched with the employers in bargaining strength."22 "Effective unions have rarely if ever been organized by 'non-committed' workers, i.e., casual workers who change jobs frequently, return periodically to their native village, and have no specific industrial skill, even of a very simple kind. In most (though by no means all) newly industrializing countries, large excess supplies of common labor are available for nonagricultural work. Not only are 
unskilled workers rarely capable of forming unions of their own under such conditions; if they succeed in doing so, their unions have little or no bargaining power." ${ }^{23}$

Given these long-lasting limitations, it should not come as a surprise that there are major regions in the world where trade unions have almost no influence. In countries with independent workers' organizations, union density (union members as percentage of the total labor force) generally has been declining. Table 1.1 reconstructs the trends in a number of countries with more than fifty million inhabitants in 2010, for the period 1960-2013.

Organized labor solidarity on a global scale is almost insignificant. Independent trade unions organize only a small percentage of their target group worldwide, and the majority of them are in the relatively wealthy North Atlantic region. By far the most important global umbrella organization is the International Trade Union Confederation (ITUC), founded in 2006 as a merger of the ICFTU and the Christian World Confederation of Labor (WCL). In 2014, the ITUC estimated that about 200 million workers worldwide belong to trade unions and that 176 million

TABLE 1.1 Union densities in selected countries with more than fifty million inhabitants in 2010.

\begin{tabular}{|c|c|c|c|c|c|c|c|}
\hline & 1960 & 1970 & 1980 & 1990 & 2000 & 2010 & 2013 \\
\hline Brazil & n.a. & n.a. & $\begin{array}{c}20.8 \\
(1976)\end{array}$ & 26.7 & 28.3 & 26.5 & 16.6 \\
\hline China (People's Republic) & n.a. & n.a. & $(58.6)$ & $(76.6)$ & $\begin{array}{l}(62.3) \\
(1997)\end{array}$ & $(34.7)$ & $(42.6)$ \\
\hline France & 19.6 & 21.7 & 18.3 & 10.0 & 8.0 & 7.9 & 7.7 \\
\hline Germany & $34.7^{\star}$ & $32.0^{*}$ & $34.9^{*}$ & 31.2 & 24.6 & 18.6 & $17.7^{\dagger}$ \\
\hline India & n.a. & n.a. & n.a. & n.a. & $\begin{array}{c}13.8 \\
(2004)\end{array}$ & $\begin{array}{c}10.2 \\
(2009)\end{array}$ & $\begin{array}{c}9.8 \\
(2012)\end{array}$ \\
\hline Italy & 24.7 & 37.0 & 49.6 & 38.8 & 34.8 & 36.0 & $36.9^{\dagger}$ \\
\hline Japan & 32.9 & 35.1 & 31.1 & 25.4 & 21.5 & 18.4 & 17.8 \\
\hline Malaysia & n.a. & n.a. & n.a. & 16.5 & 10.7 & 9.1 & 9.4 \\
\hline Mexico & & & & & $15.6^{\dagger}$ & $14.4^{\dagger}$ & $13.6^{\dagger}$ \\
\hline Philippines & n.a. & n.a. & 27.0 & 29.7 & 27.1 & 8.7 & 8.5 \\
\hline Russian Federation & & $\begin{array}{c}100.0 \\
(1968)\end{array}$ & $\begin{array}{c}100.0 \\
(1979)\end{array}$ & 72.0 & $\begin{array}{c}55.6 \\
(1999)\end{array}$ & 30.7 & 27.8 \\
\hline South Africa & n.a. & n.a. & n.a. & n.a. & $39.1^{*}$ & $29.7^{*}$ & n.a. \\
\hline South Korea & n.a. & n.a. & n.a. & n.a. & $11.4 \dagger$ & $9.7^{\dagger}$ & n.a. \\
\hline Turkey & 10.8 & 25.9 & 42.1 & 24.0 & 12.4 & 7.0 & 6.5 \\
\hline United Kingdom & 40.4 & 44.8 & 51.7 & 39.7 & 30.1 & 27.1 & $25.4^{\dagger}$ \\
\hline United States of America & n.a. & $23.5^{\diamond}$ & $19.5^{\diamond}$ & $15.5^{\diamond}$ & $12.9^{\dagger}$ & $11.4^{\dagger}$ & $10.8^{\dagger}$ \\
\hline
\end{tabular}

* Germany for 1960-1990: West Germany.

$\dagger$ OECD figures.

‡ILOSTAT.

$\diamond$ Jelle Visser, “Union Membership Statistics in Twenty-Four Countries," Monthly Labor Review, January 2006, 38-49. For lack of data, the following countries have not been included: Argentina, Bangladesh, Colombia, Democratic Republic of Congo, Egypt, Ethiopia, Indonesia, Iran, Myanmar, Nigeria, Pakistan, Tanzania, and Vietnam. 
of these are organized in the ITUC. ${ }^{24}$ The ITUC also estimates that the total number of workers is roughly 2.9 billion. Therefore, global union density currently amounts to no more than a meagre 7 percent. ${ }^{25}$

Apart from the "collective-bargaining bias," several other factors have contributed to unionism's demise. First, the composition of the working class is changing. Unions find it difficult to organize employees in the service or financial sector. The rapidly growing informal economy is complicating things further, since workers change jobs frequently and often have to earn their income under very precarious conditions. A second important factor is what labor economist Richard Freeman has called the "labor supply shock" that has manifested since the early 1990 s. Through the entry of Chinese, Indian, Russian, and other workers into the global economy, there has been an effective doubling of the number of workers producing for international markets over the past two decades. And, third, in many countries, there has been a strong neoliberal offensive against old-style unions and their modus operandi: the dominant practice of collective bargaining has increasingly become decentralized, and individualized labor contracts have become much more widespread than before. Weakened trade unions have to face more and more competition from alternative associations that are better adapted to the new-style labor relations. In Brazil, India, Pakistan, Bangladesh, South Africa, the Philippines, or South Korea, militant workers' movements (social movement unions) have emerged. New forms of rank-and-file trade unionism outside the established channels appeared since the 1970s, with international connections at the shop-floor level "bypassing altogether the secretariats, which they see as too often beholden to the bureaucracies of their various national affiliates." ${ }^{26}$ A well-known example is the Transnationals Information Exchange (TIE), an outfit in which a substantial number of research and activist labor groups exchange information on transnational corporations (TNCs). The ineffectiveness of old-style unions is underlined by the growing tendency on the part of international trade secretariats (now called Global Unions) to engage in the direct recruitment of members in the periphery. We may think, for example, of the activities of the Union Network International (the global union for the service sector) recruiting information technology (IT) specialists directly (without mediation of local unions) in India.

As before, the fight for labor rights has remained secluded within the frame of the nation-state, resulting in lukewarm interest for improving the lot of the laboring poor outside the Global North. The import of cheap durable and not-sodurable consumer goods-garments, shoes, crockery, toys, electronics, household gadgets, and a wide range of other products manufactured in homes or sweatshops in the Global South-contribute to creating the impression of ongoing welfare in the advanced economies. It is an illusion that can only be maintained in total denial of what the excessively low cost of production means for the workforce in the catch-up economies: ongoing exploitation and repression. Exemplary of the neglect and indifference are the lukewarm trade-union protests in the Global 
North not only to the recent factory fires in Bangladesh and Pakistan but also to the police brutality meted out to these factory workers when they made a faint attempt in early 2017 to back up their demand for a higher wage by going on strike.

\section{Architects of a Global Social Compact: ILO and The World Bank?}

The "globalization process" weakens labor rights across the globe. Rights are only rights if a public (national or transnational) authority is capable of enforcing them. Unenforceable claims or claims that are privately enforced should not be considered rights in a strict sense. In the field of labor rights, the International Labour Organization is a crucial institution. The ILO was set up in the wake of the social revolution that gave rise to the birth of the Soviet Union. Established under the auspices of the League of Nations, it sought to defuse an escalation of the conflict between capital and labor by calling for regulated consultations between employers and employees at the transnational level. An additional objective was the promotion of a standard model of industrial relations that would prevent unfair competition between countries marked by strikingly different modalities of waged work. These preliminary considerations were the points of departure for the tripartite formula mandated in ILO's directive: equal representation of government, employers, and employees. It was a canon that certified right from the beginning that the interests of labor would be superseded by those of the two other stakeholders.

The ILO's conventions, if ratified by member states, are guidelines for good practices at shop-floor level. Three weak spots of the ILO have to be stressed. The ILO is not only a relatively powerless organization but also reacts rather slowly to new developments. During the evolving transition to neoliberalism, the agents of government were co-opted to cater one-sidely to the demands of capital, while the trade unions that cared for the interests only of the shrinking workforce still employed in the formal economy persisted for long in looking at informal-sector workers as blacklegs. With the passing of years, the international standing of ILO has gone down. No doubt, the flexibilization of waged work is the most important reason for the erosion of ILO's mandate and agenda. All parties in the policymaking process, including the trade-union movement, have in the past decades vigorously refused to give voice to, as well as allow representation of, informalized labor in the Global South. Their vested interest in speaking up on behalf of the shrinking portion of the workforce still in the formal economy played a major role in the sustained resistance to giving a better deal to workers bereft of collective action. The wisdom of hindsight was reflected in the manifesto calling for "decent work" in 1999, but this change of hearts is nothing more than a faint effort to regain the terrain lost. The lesson learnt is that the struggle for formalization of all waged work is on the ILO's agenda. It is, indeed, a necessary although not sufficient precondition for the emancipation of the laboring classes in the world. ${ }^{27}$

The World Bank is another major global-development actor, with enormous financial, political, and knowledge-making power. Its strategic response to what 
we call the social question at the global level is "poverty alleviation," a top priority in its renewed Millennium Development Goals. But instead of tackling the structural, political, and economic sources of poverty, the bank's approach has been to reduce the problem of mass immiseration and precarity to deficient individual decision making on the part of the remaining poor, identified as a residual class to be found only in the catch-up economies. What should have been addressed as a budgetary deficit at the household level is conceived to be the lack of a predisposition to economize, self-discipline, and financial literacy of the poor, who should simply work harder to lift themselves out of poverty. ${ }^{28}$ Applying behavioral economics to development and poverty, the policy recommendations prioritized focus on "nudging" the poor to change their cognitive and psychological predispositions and the social constraints that influence economic decision making. ${ }^{29}$ This was essentially the logic of the World Bank's World Development Report 2015, even as the bank belatedly and reluctantly acknowledged that the trickle-down mechanism does not operate as earlier proclaimed. The report reads like a tour de force, a major reappraisal of policies not so long ago vigorously prescribed, but the recommendations are not followed up by any concrete steps to change the way the thoroughly deregulated labor market operates. Moreover, while targeting income inequality, the bank glosses over the even more striking issue of wealth disparity.

An indictment of the shortcomings of the poor harks back to the doctrine of economic dualism that in the colonial era portrayed the homo economicus as a creature sprouting from Western civilization, while the human gestalt in the oriental part of the world was supposed to be sadly deprived of righteous economic propensity. ${ }^{30}$ The construction of this contrast found a sequel in the dualistic distinction made between more-advanced versus less-advanced economies in the early postcolonial era, while a new and updated version of this dichotomy does not refer any longer to civilizations or countries but is conceptualized to exist between social classes. The World Bank, in its World Development Report 2015 referred to above, sets out to comprehend penury by laying stress on the misbehavior attributed to the people entrapped in this dire predicament. Only their doings and misdoings are highlighted. Apart from the biased manner in which their inadequacy is portrayed, our objection to this simplified assessment of the problem is that the societal context of poverty remains totally disregarded.

Announcing its flagship publication, "Poverty and Sharing Prosperity" (2016), the World Bank reluctantly agrees that tackling inequality is vital to ending excessive poverty by 2030, the new signpost for what is called sustainable development. How to achieve this feel-good ambition? It would require a more equal income distribution, and that means a hike in the floor price at which labor is made to sell itself, backed up, in some undefined way, by employment formalization, the bank now concedes. Our contention is that the fight against income inequality will turn out to be meaningless if the divide between wealth and poverty remains unaddressed. On further reading what sharing prosperity actually implies, it seems that 
the policies practiced so far may not have to be reformulated at all. This far-fromsurprising conclusion is reached with the argument that from 2008 to 2013, the share in income of the bottom 40 percent of the world's population has considerably gone up, and we are asked to believe that their gain in income exceeded that of the top 60 percent. It would, of course, have been setting a hopeful trend and more so, on being told that the leveling down of excessive inequality also took place at the high tide of another Great Depression of the 1930s. As usual, however, the bank's arithmetic is founded on biased and otherwise disputable statistics.

In this book, we offer an alternative analytical lens, one that shows that poverty and precarity result from loss of property-of land and other assets as well as tools and skills from the nearby or remote past-and are often compounded by dissolution or even collapse of the social fabric, state support, and the public economy. It is an argument that leads us to perceive the accumulation versus dispossession binary as processes that are not disconnected but interact in tandem. In the accelerated process of globalization, pauperism and pauperization has risen to an alarming height under the banner of predatory capitalism and has found expression in the creation of surplus people, a contingent of humankind classified as redundant to demand. ${ }^{31}$ Emphasizing the interdependency between growing wealth and impoverishment implies that a life of human quality for all requires a fundamental redistribution of the sources of existence. It is a conclusion that stands to be rejected by the stakeholders of global capitalism. The failure of half-hearted attempts at poverty alleviation, which continue to rely on the trickle-down magic and its dismal outcome, flies in the face of the good news that the marginally reformulated Millennium Development Goals will ultimately be successfully achieved.

\section{NOTES}

1. See Robert von Pöhlmann, Geschichte der sozialen Frage und des Sozialismus in der antiken Welt, 3rd ed., vol. 1 (Munich: Beck, 1925).

2. Alexis de Tocqueville, Memoir on Pauperism, trans. Seymour Drescher, (New Haven, CT: Yale University Press, 1968); reprinted and published by Civitas (London 1997), available at http://civitas. org.uk. For the classical exposition on the spiraling of the accumulation-dispossession binary, see Karl Marx, Capital, vol. 1.

3. "The master 'owes' the subject something as well, not juridically, but morally. Above all—if only in his own interest-he must protect him against the outside world and help him in need. He must also treat him 'humanely', and, especially, he must restrict the exploitation of his performance to what is 'customary.' On the ground of a domination whose aim is not material enrichment but the fulfillment of the master's own needs, he can do so without prejudicing his own interest because, as his needs cannot expand qualitatively and, on principle, unlimitedly, his demands differ only quantitatively from those of his subjects. And such restriction is positively useful to the master, as not only the security of his domination but also its results greatly depend on the disposition and mood of the subordinates. The subordinate morally owes the master assistance by all the means available to him." Max Weber, Grundriss der Sozialökonomik, III: Abteilung, Wirtschaft und Gesellschaft (Tübingen: J. C. B. Mohr, 1922), 682 . 
4. Karl Polányi, The Great Transformation: The Political and Economic Origins of Our Times (Boston: Beacon Press, 1944).

5. Karl Marx, "The Eighteenth Brumaire of Louis Bonaparte," (1851-52), Marx \& Engels Collected Works, vol. 11 (London: Lawrence and Wishart, 1976), 149.

6. Marcel van der Linden, Workers of the World: Essays toward a Global Labor History (Leiden: Brill, 2008), chaps. 5 and 6.

7. "In the 1950 and 1960 s, the labor contract for an undetermined length of time became the norm, and then served as a virtual guarantee of employment. But this stemmed only from the fact that in times of full employment, one often only hires, rarely lays off employees. As this growth [of the long boom] vanishes, however, security too disappears, and the 'indefinite' aspect of the contract reveals itself to be a simple consequence of empirical realities and not a legal guarantee.... This did not prevent most wage earners, during the years of growth, from experiencing their relationship in employment with the certitude of controlling the future and of making choices that take into account this future, such as investing in durable goods, taking out mortgages for construction, and so on." Robert Castel, From Manual Workers to Wage Laborers: Transformation of the Social Question, trans. Richard Boyd (New Brunswick, NJ: Transaction Publishers, 2003), 372-73. (Originally published in French as Les métamorphoses de la question sociale, une chronique du salariat [Paris, 1995]).

8. Jan Breman and Marcel van der Linden, "Informalizing the Economy: The Return of the Social Question at the Global Level," Development and Change, 45, no. 5 (2014): 920-40.

9. Albert Sarraut, La mise en valeur des colonies françaises (Paris: Payot, 1923).

10. John Walton and David Seddon, Free Markets and Food Riots: The Politics of Global Adjustment (Oxford: Blackwell, 1994), 46-47; Kevan Harris, "Did Inequality Breed the Arab Uprisings? Social Inequality in the Middle East from a World Perspective," in The Arab Revolution of 2011: A Comparative Perspective, ed. Saï Amir Arjomand, 87-111 (Albany, NY: State University of New York Press, 2015).

11. Edward Webster and Glenn Adler, "Toward a Class Compromise in South Africa's 'Double Transition': Bargained Liberalization and the Consolidation of Democracy” Politics and Society 27, no. 3 (1999): 347-85.

12. See, for example, Immanuel Wallerstein, "Globalization or the Age of Transition? A Long-Term View of the Trajectory of the World System," International Sociology 15, no. 2 (2000): 251-67; or Wallerstein, "Capitalism as an Essential Concept to Understand Modernity," in Capitalism: The Reemergence of a Historical Concept, ed. Jürgen Kocka and Marcel van der Linden, 187-204 (London: Bloomsbury, 2016).

13. Thomas Piketty, Capital in the Twenty-First Century (Cambridge, MA: Harvard University Press, 2013).

14. See, for example, Fritz Sternberg, Capitalism and Socialism on Trial (London: Gollancz, 1951), 62-64.

15. Gabriel Zucman, The Hidden Wealth of Nations: The Scourge of Tax Havens (Chicago: University of Chicago Press, 2015).

16. Wolfgang Streeck, "The Crises of Democratic Capitalism," New Left Review, second series, 71 (September-October 2011); and Streeck, "How Will Capitalism End?" New Left Review, second series, 87 (May-June 2014).

17. See also Jan Breman, "A Bogus Concept," New Left Review, second series, 84 (NovemberDecember 2013): 130-38.

18. Polányi, The Great Transformation.

19. Michael B. Katz, The Undeserving Poor: America's Enduring Confrontation with Poverty, and and rev. ed. (New York: Oxford University Press, 2013).

20. ICFTU, Official Report (1949), 226.

21. Sometimes they also seemed insincere. Regarding the emphasis placed by the British TUC in the 1950 os on the nonpolitical nature of "proper" trade unionism, Davies has correctly observed, "Some of these sentiments sound odd in the context of the history of the British trade union movement, which 
had supported a general strike, maintained a close association with the Labour Party, and in its annual congresses regularly debated resolutions on a large number of issues outside the field of industrial relations." D. I. Davies, “The Politics of the TUC's Colonial Policy," The Political Quarterly 35 (1964): 26.

22. Adolf Sturmthal, "Industrial Relations Strategies," in The International Labor Movement in Transition, ed. Adolf Sturmthal and James G. Scoville, 1-33 (Urbana, IL: University of Illinois Press, 1973), 9.

23. Ibid., 10.

24. This calculation is probably misleading. A significant, but unknown, part of the union membership consists of pensioners.

25. Building Workers' Power, Congress Statement (Berlin: International Trade Union Confederation, 2014), 8.

26. Andrew Herod, "Labor as an Agent of Globalization and as a Global Agent," in Spaces of Globalization: Reasserting the Power of the Local, ed. Kevin R. Cox, 167-200 (New York: Guilford Press, 1997), 184.

27. For further documentation on the ILO, see also Guy Standing, "The ILO: An Agency for Globalization?" Development and Change 39, no. 3 (2008): 355-84.

28. World Development Report 2015: Mind, Society, and Behavior (Washington DC: The World Bank, 2015).

29. Ben Fine, Deborah Johnston, Ana C Santos, and Elisa Van Waeyenberge, "Nudging or Fudging: The World Development Report 2015," Development and Change 47, no. 4 (2016): 640-63.

30. Julius H. Boeke, Economics and Economic Policy of Dual Societies, as Exemplified by Indonesia (New York: Institute of Pacific Relations, 1953). For an early array of criticism on the notion of colonial dualism, see W. F. Wertheim and others, Indonesian Economics: The Concept of Dualism in Theory and Practice (The Hague: W. van Hoeve, 1966).

31. Tania Murray Li, "To Make Live and Let Die? Rural Dispossession and the Protection of Surplus Populations," Antipode, 41, no. 1 (2010): 66-93. See also her anthropological monograph Land's End; Capitalist Relations on an Indigenous Frontier (Durham, NC: Duke University Press, 2014). 